\title{
Comparative Study Between Sublingual and Vaginal Misoprostol for Induction of Labor in Post Term Pregnant Patients with Unfavourable Cervix
}

\author{
Hossam Sobhy Mohamad Bayomi, Ismail M. El-Garhy, Ashraf Hamdy Mohamad
}

Department of Obstetrics and Gynecology, Faculty of Medicine, Al-Azhar University, Cairo, Egypt

Corresponding author: Hossam Sobhy Mohamad Bayomi, email: hossam.bayoumi7@gmail.com

\begin{abstract}
Background: Pharmacological studies suggest that sublingual route might be the optimal route of administration for PGE1 analogue misoprostol because the avoidance of the first pass hepatic circulation would yield bioavailability like that achieved with the vaginal route along with an earlier onset of action and a prolonged activity.

Objective: The aim of this study was to compare the efficacy and the safety of vaginal misoprostol with sublingual misoprostol for induction of labor in post-term pregnancy.

Subjects and Methods: This study included 50 cases, each with a singleton post-term pregnancy and a live fetus requiring induction of labor were allocated to sublingual and vaginal administration of misoprostol. Outcome measures related to labor and maternal and fetal side effects were compared between the 2 groups and evaluated using Chi square test.

Results: The sublingual route of misoprostol was associated with a reduced risk of failed induction, reduced time from initiation to induction, reduced induction to delivery interval and a higher incidence of maternal and fetal side effects. However, the differences were not statistically significant.

Conclusion: The sublingual route of administration of misoprostol is comparable in efficacy and safety to the vaginal route for induction.
\end{abstract}

Key words: Induction of labor, Misoprostol, Sublingual.

\section{INTRODUCTION}

Amongst the plethora of techniques available for induction of labor, Prostaglandins remain the single most effective means of achieving cervical ripening and inducing labor and have been administered through various routes. Pharmacological studies suggest that sublingual route might be the optimal route of administration for PGE1 analogue misoprostol because the avoidance of the first pass hepatic circulation would yield bioavailability similar to that achieved with the vaginal route along with an earlier onset of action and a prolonged activity ${ }^{(1)}$.

This has generated an interest in the sublingual route for labor induction. An additional possible advantage is that avoidance of direct cervical effects might reduce the risk of uterine hyperstimulation. Sublingual dosing for labor induction is attractive also because of ease of administration, less frequent need for vaginal examination, greater freedom of position and the possibility of its convenient use despite vaginal bleeding or ruptured membranes ${ }^{(2)}$.

A few studies have found that sublingual administration of misoprostol is also effective for induction of labour ${ }^{(3)}$.

The aim of this study was to compare the efficacy and the safety of vaginal misoprostol with sublingual misoprostol for induction of labor in post-term pregnancy.

\section{SUBJECTS AND METHODS}

This study included a total of 100 pregnant women whose gestational ages were beyond 42 weeks attending at Department of Obstetrics and Gynecology, In Al-Azhar University Hospitals. Approval of the ethical committee and a written informed consent from all the subjects were obtained. This study was conducted between September 2017 and May 2018. Subjects were divided into two groups as follows:

I- Group I: This group included 50 pregnant women who received vaginal misoprostol in a dose of $25 \mu \mathrm{g}$ to be repeated every 4 hours if no response was achieved with a maximum of 6 doses. This dose was placed in the posterior fornix of the vagina. (1 tablet of Vagiprost, Adwia, Egypt).

II- Group II: This group included 50 pregnant women who received sublingual misoprostol in a dose of $50 \mu \mathrm{g}$ to be repeated every 4 hours if no response was achieved with a maximum of 6 doses. This dose was placed under the tongue till completely dissolved. (1/4 of Misotac tablet, Sigma, Egypt). In both groups gestational age was determined by reliable history of dating of the last menstrual period with regular cycles and / or sonography at first trimester. Unification of the baseline characteristics between both groups was attempted. This study was approved by Al-Azhar University hospitals and 
informed consent for participation was obtained from each study participant. The nature of the study was explained to all patients and they were willing to have their results registered in this study.

Inclusion criteria: Post term pregnant female (beyond 42 weeks gestation). Singleton pregnancies. Vertex presentation. Normal fetal heart tracing. Unfavorable cervix (a cervix that is not adequately prepared for a vaginal delivery of a newborn child "one with a Bishop's score of 6 or less")

Exclusion criteria: Twin pregnancy. Abnormal fetal presentation. Fetal macrosomia (>4 Kgms). Previous uterine scar. Placenta previa centralis and marginalis posterior. Absolute contraindication for induction of labor as (inadequate pelvis, severe oligohydramnios, placental insufficiency). High risk pregnancy (a pregnancy that threatens the health or life of the mother or her fetus e.g. elevated blood pressure or diabetes mellitus.

A detailed history, general physical examination and Obstetrical examination were carried out. Per vaginum examination was done for assessing bishop's score and pelvis. Subjects meeting the above criteria with no contraindication to vaginal delivery were allocated alternately in each group. Failure of induction was defined as unfavourable cervix after 5 doses (evaluated 4 hours after last dose). The subsequent dose was withheld in the presence of any of the following: at least three regular uterine contractions in 10 minutes, active phase of labor (defined as regular uterine contractions with cervical dilation $>3 \mathrm{~cm}$ ), cervix favorable for amniotomy (Bishop score >8). As soon as fetal head engagement and cervical dilation permitted, amniotomy was performed, followed by oxytocin augmentation if the frequency of contractions was less than three per 10 minutes or the contractions pattern was dysfunctional. Oxytocin was administered not earlier than 4 hours after the last misoprostol dose, starting at $1 \mathrm{mU} /$ minute and increased by $1 \mathrm{mU} /$ minute every 15 minute until adequate contractions persisted. If the woman went into labor or if the Bishop's score was 8 or more, an artificial rupture of membranes was performed. Induction of labor was considered to have failed when cervix was unfavorable (Bishop's score $<8$ ) after 5 doses of misoprostol (evaluated 4 hours after last dose). If there was failure of induction, caesarean section was performed.

During entire intrapartum period strict monitoring of fetal heart rate and rhythm was done $\&$ uterine activity was monitored for tachysystole, hypertonus and hyper stimulation syndrome.

Determination of the outcomes: Primary outcomes: successful induction of labor is measured by several factors that include inductiondelivery interval, mode of delivery, number of doses given, number of women given oxytocin. Secondary outcomes: Any maternal obstetric complications: such as uterine hyperstimulation, antepartum hemorrhage, postpartum hemorrhage. Any fetal complications: all neonates were subjected to Apgar scoring at 5 minutes then neonatal morbidity was considered by the following criteria: Apgar score less than 6 at 5 minutes, fetal academia, neonatal admission to the Neonatal Intensive Care Unit(NICU), neonatal birth weight(NBW). Side effects of misoprostol: such as nausea, vomiting, diarrhea or hyperthermia.

Statistical analysis: The data was analyzed with the help of computer software SPSS version 12.0 for windows. Statistically significant differences were evaluated using Chi square test. $\mathrm{P}$ value of $<0.05$ was considered as statistically significant.

\section{RESULTS}

Table (1) shows that no statistically significant difference was found between the two groups regarding their baseline characteristics which denote homogeneity of the two groups.

Table (1): Distribution of patients in both groups (50 cases in each group) by their Baseline characteristics (Age, Parity, Previous abortion, Bishop score, EFW by U/S, Body mass index-BMI-).

\begin{tabular}{|c|c|c|c|c|c|}
\hline \multicolumn{2}{|c|}{ Item } & $\begin{array}{c}\text { Group I } \\
\text { (vaginal) } \\
\text { No }=\mathbf{5 0}\end{array}$ & $\begin{array}{c}\text { Group II } \\
\text { (sublingual) } \\
\text { No }=\mathbf{5 0}\end{array}$ & $\begin{array}{c}P \\
\text { value }\end{array}$ & $\mathbf{T}$ \\
\hline \multicolumn{2}{|r|}{ Age } & $25.27 \pm 3.523$ & $26.23 \pm 2.725$ & 0.240 & -1.189 \\
\hline \multirow{4}{*}{ 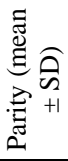 } & Primipara & 10 cases & 9 cases & 0.423 & -0.856 \\
\hline & Para 1 & 12 cases & 13 cases & 0.560 & -0.586 \\
\hline & Para 2 & 13 cases & 12 cases & 0.356 & -0.624 \\
\hline & Para $\geq 3$ & 15 cases & 16 cases & 0.521 & -0.238 \\
\hline \multicolumn{2}{|c|}{$\begin{array}{c}\text { Previous } \\
\text { abortion }\end{array}$} & $0.37 \pm 0.765$ & $0.50 \pm 0.731$ & 0.493 & -0.690 \\
\hline \multicolumn{2}{|c|}{ Bishop score } & $4.63 \pm 0.556$ & $4.87 \pm 0.681$ & 0.152 & -1.453 \\
\hline \multicolumn{2}{|c|}{ EFW by U/S } & $3.283 \pm 0.126$ & $3.277 \pm 1.331$ & 0.843 & -0.199 \\
\hline \multicolumn{2}{|r|}{ BMI } & $\begin{array}{c}19.864 \pm \\
2.145\end{array}$ & $\begin{array}{c}20.324 \pm \\
1.023\end{array}$ & 0.234 & -0.964 \\
\hline
\end{tabular}


Table (2) shows that the mean of the induction to delivery interval in group I was $12.03 \pm$ 4.004 hours while in group II was $11.68 \pm 3.475$ hours. No statistically significant difference between the two groups was found $(\mathrm{T}=-0.358, \mathrm{P}=0.722)$ which denotes homogenecity of the two groups.

Table (2): Distribution of patients in both groups by their induction to delivery interval.

\begin{tabular}{|l|c|c|c|c|}
\hline \multicolumn{1}{|c|}{ Item } & $\begin{array}{c}\text { Group I } \\
\text { (Vaginal) } \\
\text { No= 50 }\end{array}$ & $\begin{array}{c}\text { Group II } \\
\text { (Sublingual) } \\
\text { No= 50 }\end{array}$ & P value & T \\
\hline $\begin{array}{l}\text { Induction to } \\
\text { delivery interval } \\
\text { (mean } \pm \text { SD) }\end{array}$ & $12.03 \pm 4.004$ & $11.68 \pm 3.475$ & $\begin{array}{c}0.722 \\
\text { (NS) }\end{array}$ & -0.358 \\
\hline
\end{tabular}

Table (3) shows that the number of patients who needed oxytocin augmentation in the vaginal group was 32 cases $(64 \%)$ and in the sublingual group was 30 cases $(60.0 \%)$. No statistically significant difference between the two groups was found $(\mathrm{P}=0.791)$.

Table (3): Number of cases which needed oxytocin augmentation.

\begin{tabular}{|c|c|c|c|c|}
\hline Item & $\begin{array}{c}\text { Group I } \\
\text { (Vaginal) } \\
\text { No }=\mathbf{5 0}\end{array}$ & $\begin{array}{c}\text { Group II } \\
\text { (Sublingual) } \\
\text { No }=\mathbf{5 0}\end{array}$ & $\begin{array}{c}\mathbf{P} \\
\text { value }\end{array}$ & $\mathbf{T}$ \\
\hline $\begin{array}{l}\text { Oxytocin } \\
\text { augmentation } \\
\text { (Number of } \\
\text { cases) }\end{array}$ & $\begin{array}{c}32 \text { cases } \\
(64 \%)\end{array}$ & $\begin{array}{c}30 \text { cases } \\
(60 \%)\end{array}$ & $\begin{array}{c}0.791 \\
(\mathrm{NS})\end{array}$ & 0.712 \\
\hline
\end{tabular}

Table (4) shows that the number of maternal obstetric complications in the vaginal group were: a) Antepartum hemorrhage 3 cases (6\%), b) Postpartum hemorrhage 5 cases $(10 \%)$, c) Uterine hyperstimulation 5 cases $(10 \%)$. The number of maternal complications in sublingual group were: a) Antepartum hemorrhage 2 cases (4\%), b) Postpartum hemorrhage 6 cases (12\%), c) Uterine hyperstimulation 7 cases (14\%). No statistically significant difference between the two groups was found $(\mathrm{P}=0.688$ for antepartum hemorrhage, $\mathrm{P}=0.657$ for postpartum hemorrhage, $\mathrm{P}=0.732$ for uterine hyperstimulation).

Table (4): Maternal obstetric complications in both groups.

\begin{tabular}{|l|c|c|c|c|}
\hline \multicolumn{1}{|c|}{$\begin{array}{c}\text { Maternal } \\
\text { complications }\end{array}$} & $\begin{array}{c}\text { Group I } \\
(\text { Vaginal) } \\
\text { No= 50 }\end{array}$ & $\begin{array}{c}\text { Group II } \\
\text { (Sublingual) } \\
\text { No= 50 }\end{array}$ & $\begin{array}{c}\text { P } \\
\text { value }\end{array}$ & T \\
\hline $\begin{array}{l}\text { Antepartum } \\
\text { hemorrhage }\end{array}$ & $\begin{array}{c}3 \text { cases } \\
(6 \%)\end{array}$ & 2 cases (4\%) & 0.688 & 0.103 \\
\hline $\begin{array}{l}\text { Postpartum } \\
\text { hemorrhage }\end{array}$ & $\begin{array}{c}5 \text { cases } \\
(10 \%)\end{array}$ & 6 cases (12\%) & 0.657 & 0.116 \\
\hline $\begin{array}{l}\text { Uterine } \\
\text { hyperstimulation }\end{array}$ & $\begin{array}{c}5 \text { cases } \\
(10 \%)\end{array}$ & 7 cases $(14 \%)$ & 0.732 & 0.131 \\
\hline
\end{tabular}

Table (5) shows that the distribution of neonatal complications in the vaginal group was: a) Low Apgar score $<7$ at 5 minutes 3 cases $(6 \%)$, b) NICU admission 4 cases (8\%), Low neonatal birth weight $<2.5 \mathrm{~kg}$. 3 cases $(6 \%)$. The distribution of neonatal complications in the sublingual group was: a) Low Apgar score $<7$ at 5 minutes 2 cases (4\%), b) NICU admission 3 cases (6\%), Low neonatal birth weight $<2.5 \mathrm{~kg}$. 5 cases $(10 \%)$.

No statistically significant difference between the two groups was found $(\mathrm{P}=0.577$ for low Apgar score, $\mathrm{P}=0.554$ for NICU admission, $\mathrm{P}=0.286$ for low neonatal birth weight).

Table (5): Neonatal complications in both groups.

\begin{tabular}{|l|c|c|c|c|}
\hline $\begin{array}{c}\text { Neonatal } \\
\text { complications }\end{array}$ & $\begin{array}{c}\text { Group I } \\
\text { (Vaginal) } \\
\text { No= 50 }\end{array}$ & $\begin{array}{c}\text { Group II } \\
\text { (Sublingual) } \\
\text { No= 50 }\end{array}$ & $\begin{array}{c}\text { P } \\
\text { value }\end{array}$ & T \\
\hline $\begin{array}{l}\text { Low Apgar } \\
\text { score < 7 at 5 } \\
\text { minutes }\end{array}$ & $\begin{array}{c}3 \text { cases } \\
(6 \%)\end{array}$ & 2 cases (4\%) & 0.577 & 0.561 \\
\hline NICU admission & $\begin{array}{c}4 \text { cases } \\
(8 \%)\end{array}$ & 3 cases (6\%) & 0.554 & 0.602 \\
\hline $\begin{array}{l}\text { Low neonatal } \\
\text { birth weight }< \\
2.5 \mathrm{~kg} .\end{array}$ & $\begin{array}{c}3 \text { cases } \\
(6 \%)\end{array}$ & 5 cases (10\%) & 0.286 & 1.078 \\
\hline
\end{tabular}

Table (6) shows that the distribution of side effects of misoprostol in the vaginal group was: a) nausea 3 cases $(6 \%)$, b) vomiting 4 cases $(8 \%)$, c) diarrhea 3 cases $(6 \%)$, d) hyperthermia 5 cases $(10 \%)$.

The distribution of side effects of misoprostol in the sublingual group was a) nausea 2 cases $(4 \%)$, b) vomiting 3 cases $(6 \%)$, c) diarrhea 5 cases $(10 \%)$, d) hyperthermia 6 cases $(12 \%)$.

No statistically significant difference between the two groups was found $(\mathrm{P}=0.577$ for nausea, $\mathrm{P}=0.554$ for vomiting, $\mathrm{P}=0.286$ for diarrhea, $\mathrm{P}=0.365$ for hyperthermia)

Table (6): Side effects of misoprostol in both groups.

\begin{tabular}{|l|c|c|c|c|}
\hline \multicolumn{1}{|c|}{ Side Effects } & $\begin{array}{c}\text { Group I } \\
(\text { Vaginal) } \\
\text { No= 50 }\end{array}$ & $\begin{array}{c}\text { Group II } \\
\text { (Sublingual) } \\
\text { No= 50 }\end{array}$ & $\begin{array}{c}\text { P } \\
\text { value }\end{array}$ & T \\
\hline Nausea & $\begin{array}{c}3 \text { cases } \\
(6 \%)\end{array}$ & 2 cases (4\%) & 0.577 & 0.561 \\
\hline Vomiting & $\begin{array}{c}4 \text { cases } \\
(8 \%)\end{array}$ & 3 cases (6\%) & 0.554 & 0.602 \\
\hline Diarrhea & $\begin{array}{c}3 \text { cases } \\
(6 \%)\end{array}$ & 5 cases $(10 \%)$ & 0.286 & 1.078 \\
\hline Hyperthermia & $\begin{array}{c}5 \text { cases } \\
(10 \%)\end{array}$ & 6 cases (12\%) & 0.365 & 0.985 \\
\hline
\end{tabular}




\section{DISCUSSION}

In our study we found that $50 \mu \mathrm{g}$ sublingually administered misoprostol is similarly effective as $25 \mu \mathrm{g}$ vaginal misoprostol with respect to our primary outcome.

There was no significant difference in the number of pregnant women who delivered within the first 24 hours which was $41(82 \%)$ in vaginal group and $38(76 \%)$ in sublingual group.

Regarding induction-delivery interval the difference between vaginal and sublingual groups was non-significant $12.03 \pm 4.004$ vs. $11.68 \pm$ $3.475, \mathrm{p} \geq 0.05$.

Regarding maternal or neonatal complications the difference between vaginal and sublingual groups was non-significant, $\mathrm{P} \geq 0.05$.

The pharmacokinetic studies that have shown that the peak plasma concentration and bioavailability after a single dose of misoprostol are higher after sublingual administration than those after vaginal administration. This may be explained by the absence of a first-pass effect by the liver after sublingual administration. The good blood supply under the tongue and the relatively neutral $\mathrm{pH}$ in the buccal cavity may also be contributing factors ${ }^{(1)}$.

The sublingual route has been shown to produce significantly higher serum peak concentration of misoprostol than vaginal administration. In addition, the area under the curve for plasma levels over 4 and 6 hours was significantly greater following sublingual administration than for vaginal administration ${ }^{(4)}$.

A recently published study evaluated the effects of misoprostol on uterine contractility following different routes of administration. The sublingual application of misoprostol has, with regard to effects on the myometrium, at least as rapid an effect on uterine contractility as oral administration and is similar to that following vaginal administration ${ }^{(2)}$.

These findings may explain the shorter induction to delivery interval with sublingual misoprostol than vaginal misoprostol in our study, that is still non-significant difference $(\mathrm{P}=0.722)$. It must, however, be emphasized that we compared a higher sublingual dose $(50 \mathrm{mg})$ with a lower dose of vaginal misoprostol $(25 \mathrm{mg})$. This approach was adopted because data from two previous studies ${ }^{(5)}$.
Comparing $50 \mathrm{mg}$ of sublingual with 50 or $100 \mathrm{mg}$ of oral misoprostol for labor induction, suggested that $50 \mathrm{mg}$ of misoprostol administered sublingually might be the optimal dose that maintains the balance between efficacy and safety and a dose that might not have been effective was not acceptable.

Different routes of misoprostol administration for labor induction necessitate carefully balancing the benefit (shorter induction to delivery interval) against the risk (uterine hyperstimulation, adverse neonatal and maternal outcomes). The considerably higher rate of tachysystole with $50 \mathrm{mg}$ of misoprostol given sublingually when compared with vaginal administration of $25 \mathrm{mg}$ was a cause for concern, even though similar rates of hypertonus and hyperstimulation syndrome were observed. This suggests that avoidance of a direct effect on the cervix did not reduce the risk of excessive uterine activity ${ }^{(6)}$.

Zahran et al. evaluated sublingual versus vaginal misoprostol for induction of labor at postterm, but in randomized prospective placebo controlled study. We found similar results like Zahran et al study as fetal distress in both group had the highest frequency, but there was no difference between groups in case of induction to delivery interval, duration of labor, neonatal outcome or maternal side effects ${ }^{(7)}$. However in comparison to their study, we found low number of attributed labors that had meconium staining in both studied groups, but less active labor in sublingual group. They found sublingual route promised to higher patient's satisfaction level. Although we didn't evaluate the patients' satisfaction level in our results.

Akare and Patel conducted a study at Department of Obstetrics and Gynecology, Medical College, Baroda, Gujarat, India. 2 groups 50 cases each with a singleton post-term pregnancy and a live fetus requiring induction of labor were allocated to sublingual and vaginal administration of misoprostol. Outcome measures related to labor and maternal and fetal side effects were compared between the 2 groups. The results revealed that the sublingual route of misoprostol was associated with a reduced risk of failed induction, reduced time from initiation to induction, reduced induction to delivery interval and a higher incidence of maternal and fetal side effects. However, the differences were not statistically significant ${ }^{(8)}$. The results of this study are consistent to our study. 
Bartusevicius et al. designed a doubleblinded, randomized controlled trial to compare the efficacy and safety of $50 \mathrm{mg}$ of sublingual misoprostol with $25 \mathrm{mg}$ of vaginal misoprostol administered for labor induction on a total of 140 pregnant women at post-term and concluded that a $50 \mathrm{mg}$ of sublingual misoprostol 4 hourly for labor induction at post-term seems to have similar efficacy as $25 \mathrm{mg}$ of vaginal misoprostol ${ }^{(3)}$. The results of this study are consistent to our study.

Moraes-Filho et al. performed a randomized controlled clinical trial to compare the effectiveness and safety of sublingual misoprostol $(25 \mu \mathrm{g})$ versus vaginal misoprostol $(25 \mu \mathrm{g})$ for labor induction with gestational age $\geq 37$ weeks and unripe cervices. The results revealed that $25 \mu \mathrm{g}$ of sublingual misoprostol every $6 \mathrm{~h}$. presented the same effectiveness and safety as an equal vaginally administered dose of this substance ${ }^{(9)}$. The results of this study correlates with our study as there were no statistically significant differences between the vaginal and sublingual groups in the inductiondelivery interval, the number of vaginal deliveries, but this study differs in the number of doses used, number of patients enrolled in the study and the gestational age of the patients.

Although the research has reached its aims, there are still some limitations. First, because of the time limit, this research was conducted only on a small size of population who attended our hospital during research period. Therefore, to generalize the results for larger groups, it would be better if it was done in a longer time. Other limitations may involve that lack of blinding in our study as the nature of the study has been explained to all participants. There is no time or place for long term follow up of all participants that if was present it would help us to determine more outcomes of the study such as post-partum hemorrhage, postpartum depression.

Further future studies should take into consideration increasing the study base through increasing the sample size and the duration of the trial to be more representative and eliminate any bias that may occur.

\section{CONCLUSION}

Induction of labor in post-term pregnant women with unfavorable cervix with either $25 \mu \mathrm{g}$ vaginal misoprostol or $50 \mu \mathrm{g}$ sublingual misoprostol seems to be effective, safe, low cost and worthy to induce labor without forgetting the precautions we mentioned and close observation to the mother and fetus.

\section{REFERENCES}

1. Tang OS, Schweer H, Seyberth HW, Lee SW, Chung Ho (2002): Pharmacokinetics of different routes of administration of misoprostol. Hum. Reprod.,17(2):332-6.

2. Aronsson A, Bygdeman M, GemzellDanielsson K (2004): Effects of misoprostol on uterine contractility following different routes of administration. Hum Reprod; 19(1):81-4.

3. Bartusevicius A, Barcaite E, Krikstolaitis R, Gintautas V, Nadisauskiene $R$ (2006): Sublingual compared with vaginal misoprostol for labour induction at term: a randomised controlled trial. BJOG.,113:1431-7.

4. Zieman M, Fong SK, Benowitz DL, Banskter D, Darney PD (1997): Absorption kinetics of misoprostol with oral or vaginal administration.Obstet Gynecol., 90:88 - 92.

5. Shetty A, Mackie L, Danielian $\mathbf{P}$, Rice $\mathbf{P}$, Templeton A (2002): Sublingual compared with oral misoprostol in term labor induction: a randomized controlled trial. BJOG., 109:645-50.

6. Danielsson KG, Marions L, Rodriquez A, Spur BW, Wong PY, Bygdeman M (1999): Comparison between oral and vaginal administration of misoprostol on uterine contractility. Obstet Gynecol., 93:275- 80.

7. Zahran KM, Shahin AY, Abdellah MS, Elsayh KI (2009): Sublingual versus vaginal misoprostol for induction of labor at term: a randomized prospective placebo-controlled study. J Obstet. Gynaecol. Res.,35:1054-1060.

8. Akare MD, Patel PK (2017): A comparison of sublingual with vaginal administration of misoprostol for induction of labor at post-term. Int J Reprod Contracept Obstet Gynecol., 6:1398-403.

9. Moraes-Filho O, Albuquerque R, Pacheco A et al. (2005): Sublingual versus vaginal misoprostol for labor induction of term pregnancies. Rev Bras Ginecol Obstet., 27: 20-23. 